\title{
FABRIC ARCHITECTURE IN EGYPT
}

\author{
Mohamed Zakaria EIDars, Dr.Algendy Shaker Algendy, Soha Aboubakr Ahmed \\ Al-Azhar University, Department of Architecture, Cairo, Egypt.
}

\begin{abstract}
With the development of fabric architecture all over the world, because of its lightweight, high efficiency, low cost, design flexibility, portable and friendly to natural, we notice that its application levels in Egypt is very low on both sides; the number of executed projects and the technical level of the projects.

After studying of fabrics membrane types and their properties then comparing them to the applied projects in Egypt we find that referred to economic and cultural reasons; fabric architecture in Egypt needs more time and development to could met the world level.
\end{abstract}

Keywords : Fabric structures; Fabric architecture; textile architecture; tensile structures; Fabric coatings; Fabric façade; Tensile façade.

\section{INTRODUCTION:}

Being lightweight and flexible; fabric interacts better with natural forces than a rigid material, this combined with its daytime translucency and night-time luminosity gives a magical feeling of being outdoors, combined with the security and comfort of indoors www.buildnova.com. Architectural fabric structures are a form of building that can almost be considered a contradiction in terms. Fabrics represent some of the lightest artefacts made by humanity, and yet, buildings represent some of the heaviest. Because of their lightweight nature, fabrics are also flexible and mobile, whilst buildings, at least in their traditional sense, are solid and permanent. However, fabric architecture does exist and has for millennia as one of the earliest forms of building to be manufactured on a regular and widespread basis. It is also one of our most advanced and innovative forms of building, which continues to develop rapidly today, and almost certainly into the fore-seeable future. As well as being light in weight and economic in materials, they have a close relationship to nature that is derived from their frugal response to structural requirements. For this reason, fabric architecture is often described as sensual and organic. These are buildings that touch the earth lightly with a physical impact and charismatic image in tune with a world that is becoming ever more concerned about ecology and sustainability (Josep Ignasi de LIorens 2015).

By their nature tensile membrane structures are designed to cover large areas with lightweight material (commonly around $1 \mathrm{~kg} / \mathrm{m} 2$ ) (Chilton 2009).

\section{Research methodology:}

Using an analytic descriptive method to study the fabric architecture buildings, advantages, disadvantages, facades and the fabric future in construction field. Due to the lack of documented information, the research relied on data from the construction companies in Egypt.

\section{What are Fabric Structures?}

Fabric structures are thin shelled structures made out of polyester or woven fabric, protected with coatings or laminations. Membrane joints are usually glued or welded together, while clamp plates, bale rings, or membrane plates are used to connect the membrane to its supporting structure. Different arrangement and direction of fabric warps produce different strength values. 


\section{The fabric material}

Fabric material consists of woven threads (the weave) onto which, on one or both sides, a coating is applied first and the threads are discussed, followed by weaving methods. After that, coatings are explained.

Threads: A thread is built up out of fibres. There are two types of it:

$\checkmark$ Natural fibres have a restricted length and are bound up in strands.

$\checkmark$ Chemical fibres have a theoretically endless length and are called filaments.

The shape of the cross-section is round for natural fibres but can have any shape in chemical fibres.

The fibres: There are several fibres that are being applied in membrane structures. For each project, it is necessary to consider which type of fabric can be used. Most of the commonly used fibres are chemical fibres, particularly nonorganic polymer fibres.

\section{1. Fabrics membrane}

Most fabric structures are composed of actual fabric rather than meshes or films. Typically, the fabric is coated and laminated with synthetic materials for increased strength, durability, and environmental resistance. Among the most widely used materials are polyesters laminated or coated with polyvinyl chloride (PVC), and woven fiberglass coated with polytetrafluoroethylene PTFE (www.ifai.com).

\section{- Fabrics Membrane types}

1. Organic cotton fibre

2. Polymer polyester

3. Polymer polyamide (PA or nylon)

4. Polymer polyethylene (PE)

5. Nonorganic fibreglass

6. Polymer fluor polymer fibres

7. Polymer aramid fibre

8. Polymer Vectran fibre

Table (1): Fabric membranes (uncoated) properties

\begin{tabular}{|c|c|c|c|c|}
\hline \multirow{2}{*}{$\begin{array}{c}\text { Fabric } \\
\text { Membrane }\end{array}$} & \multicolumn{2}{|r|}{ Properties } & Usage & \multirow[t]{2}{*}{ Coatings } \\
\hline & Advantages & Disadvantages & & \\
\hline $\begin{array}{l}\text { Organic } \\
\text { cotton fibre }\end{array}$ & $\begin{array}{lr}\text { Have a } & \text { high } \\
\text { ultraviolet } & \text { UV } \\
\text { resistance. } & \end{array}$ & $\begin{array}{l}\begin{array}{l}\text { Subject } \\
\text { moisture }\end{array} \\
\text { to fungi and }\end{array}$ & $\begin{array}{l}\text { Frei Otto used it for } \\
\text { his early garden } \\
\text { show structures - } \\
\text { nowadays in some } \\
\text { rental tents. }\end{array}$ & \\
\hline Polyesters & $\begin{array}{ll}\text { Strength, } & \text { cost } \\
\text { durability, } & \text { and } \\
\text { stretch } & \end{array}$ & $\begin{array}{l}\text { The mechanical properties } \\
\text { decrease with UV light, and } \\
\text { it is subject to ageing. }\end{array}$ & $\begin{array}{l}\text { Most widely used in } \\
\text { fabric structures } \\
\text { Polyester with } \\
\text { fibreglass is the } \\
\text { most common fibre } \\
\text { in textile } \\
\text { architecture. }\end{array}$ & $\begin{array}{l}\text { Laminated/coated } \\
\text { with PVC films are } \\
\text { usually the least } \\
\text { expensive option for } \\
\text { longer-term } \\
\text { fabrications. }\end{array}$ \\
\hline $\begin{array}{l}\text { Polymer } \\
\text { polyamide } \\
\text { (nylon } \\
\text { fibres) }\end{array}$ & $\begin{array}{l}\text { Compared to other } \\
\text { polymer fibres, the } \\
\text { strength, stiffness } \\
\text { and tenacity are } \\
\text { high. }\end{array}$ & $\begin{array}{l}\text { When the fibre gets wet, it } \\
\text { swells in length.so it is } \\
\text { difficult to control the size of } \\
\text { the panels. It also has poor } \\
\text { resistance to UV light. }\end{array}$ & & \\
\hline $\begin{array}{l}\text { Polymer } \\
\text { polyethylene }\end{array}$ & $\begin{array}{l}\text {-low self-weight } \\
\text { and are able to } \\
\text { float in water. } \\
\text {-it is a } \\
\text { thermoplastic } \\
\text { 00material. It can } \\
\text { be recycled well. }\end{array}$ & $\begin{array}{l}\text { Has a low surface adhesion } \\
\text { so it is difficult to use the } \\
\text { fibres in coated applications. } \\
\text { If it is treated with a special } \\
\text { pre-coating, it is possible. }\end{array}$ & & \\
\hline Nonorganic & Has high tensile & Has brittle behaviour and & & \\
\hline
\end{tabular}




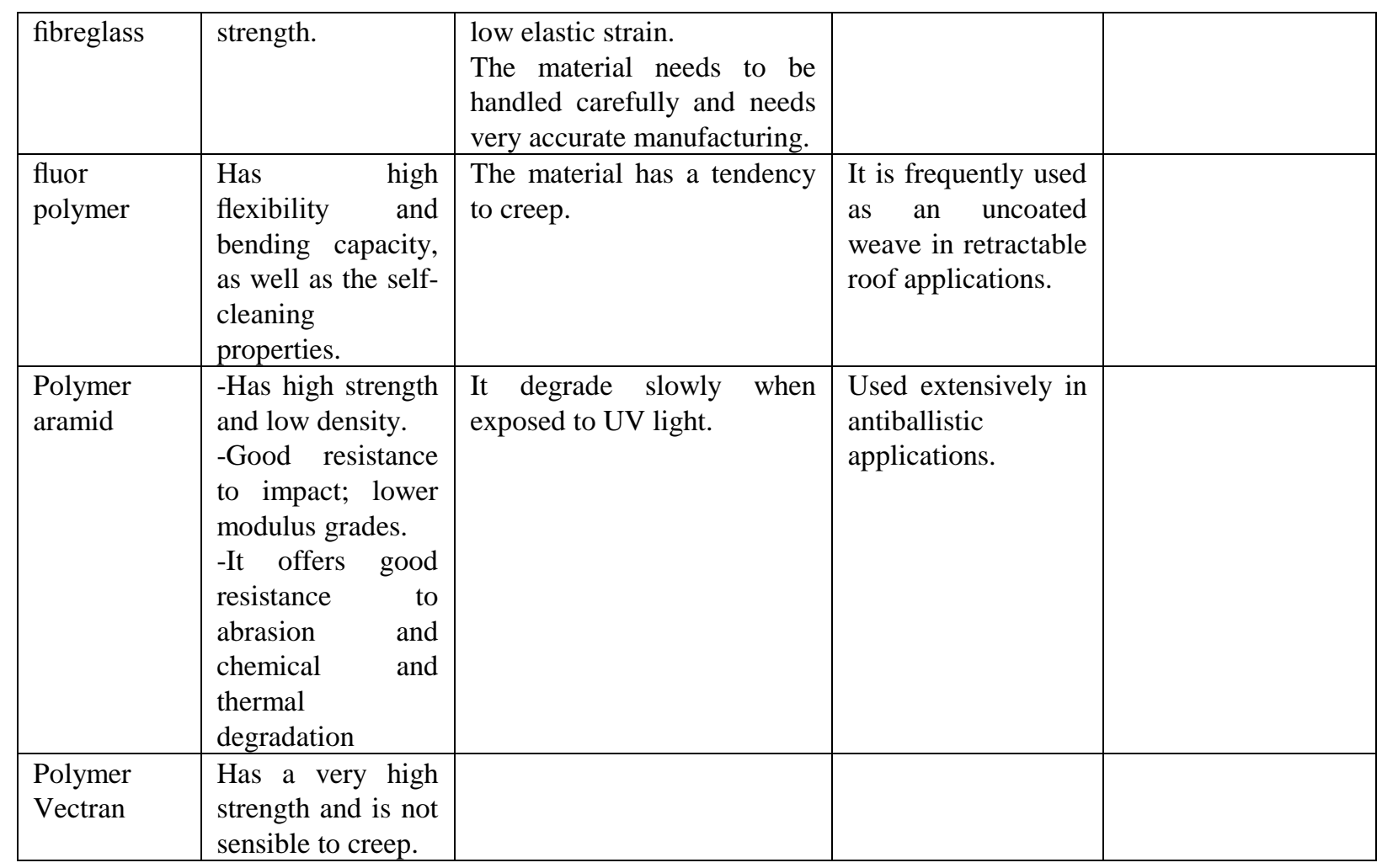

\section{2. Composition of the base material}

Fabric that is normally used for membrane structures is built up out of a woven structural base material, to which a covering on both sides is applied to protect it from water and pollutants, the so-called coating. In the other hand, coating gives physical abilities to the fabric such as, water-proofing, light reflectance and self-cleaning.

There are two methods for composition of the fabric, plain wove and cross wove. Choice of method affects the depth of the fabric and the ability. Fabric in thicker size will need more coating and so the cost. Three types of coated fabrics have accounted for 90 percent of all fabrics used in modern architectural projects: PTFE (Poly tetra fluoro ethylene)-coated fiberglass; PVC (Polyvinyl chloride)-coated polyester; and ETFE (Ethylene tetra fluoro ethylene

)-coated foil. In addition to these three main fabrics, there are a lot of others. 


$\begin{array}{ll}\text { - Acrylic painted cotton. } & \text { - Hypalon coated polyester. } \\ \text { - Neoprene coated nylon. } & \text { - Polyolefin coated polyester. } \\ \text { - Hypalon coated nylon. } & \text { - PTFE coated polypropylene. } \\ \text { - Polyester coated cotton. } & \text { - PTFE coated aramid. } \\ \text { - Vinyl coated cotton. } & \text { - PTFE coated polyester. } \\ \text { - ETFE coated glass. } & \text { - PTFE coated acrylic. } \\ \text { - PVF coated glass. } & \text { - ETFE coated polyester. } \\ \text { - PVC coated aramid. } & \text { - PVDF coated polyester. } \\ \text { - PVDF coated glass. } & \text { - Vinyl coated polyester. } \\ \text { - Vinyl coated nylon. } & \text { - Vinyl laminated polyester. } \\ \text { - Polyurethane coated nylon. } & \text { - Acrylic coated polyester }\end{array}$

- Acrylic painted cotton.

- Neoprene coated nylon.

- Hypalon coated nylon.

- Polyester coated cotton.

- Vinyl coated cotton.

- etfE coated glass.

- PVF coated glass.

- PVC coated aramid

- Vinyl coated nylon.

- Polyurethane coated nylon.
- Hypalon coated polyester.

- Polyolefin coated polyester.

- PTFE coated polypropylene.

- PTFE coated aramid.

- PTFE coated polyester.

- PTFE coated acrylic.

- ETFE coated polyester.

- PVDF coated polyester.

- Vinyl coated polyester.

- Acrylic coated polyester

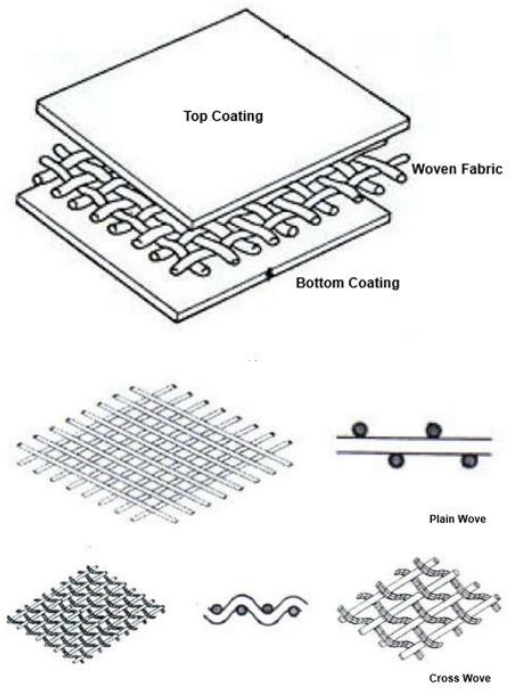

Fig (1): Composition of the fabric. (https://www.designingbuildings.co.uk) Source:(Josep Ignasi de LIorens 2015)

\section{3. Fabric Coatings:}

Most of the fibres need a coating on both sides. Moreover, a coating is often used to create a smooth surface and, thereby, reduce the potential pollution area. There are several coatings available. The coating is often used to weld the different parts of the membrane together. The adhesion of the coating to the fabric is an indication of the strength of the seams (Josep Ignasi de LIorens 2015).

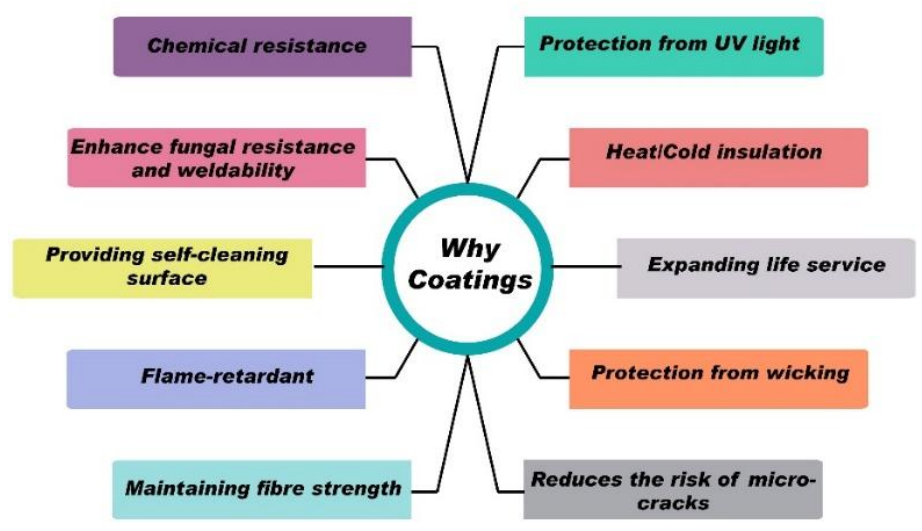

Fig (3): Benefits of coatings. 
1- Coating on Cotton fabric

2- $\quad$ PVC coating on polyester cloth

3- ETFE-coated foil

4- Silicone coating on fibreglass weave

5- $\quad$ PTFE coating on fibreglass weave

6- $\quad$ PVC, PTFE or silicone coating on aramid weave

7- PTFE fabric (coated and non-coated)

8- PVDF fabric

Table (2): Coated fabrics material properties. source : (Josep Ignasi de LIorens 2015)

\begin{tabular}{|c|c|c|c|c|c|c|}
\hline \multirow[t]{2}{*}{ Coating } & \multirow[t]{2}{*}{ Fabric } & \multirow[t]{2}{*}{ Properties } & \multirow[t]{2}{*}{ Usage } & \multicolumn{3}{|c|}{ Manufacturing } \\
\hline & & & & Techniques & Cost & $\begin{array}{c}\text { Service } \\
\text { life }\end{array}$ \\
\hline ----- & $\begin{array}{l}\text { Cotton } \\
\text { fabric }\end{array}$ & $\begin{array}{l}\text { It is often impregnated with a silicone } \\
\text { spray to make it watertight. To } \\
\text { improve the strength and durability of } \\
\text { the material, it is often blended with } \\
\text { polyester }\end{array}$ & $\begin{array}{l}\text { Small-scale } \\
\text { temporary } \\
\text { structures, not } \\
\text { frequently } \\
\text { used }\end{array}$ & Stitching & & $\begin{array}{l}\text { four to } \\
\text { five } \\
\text { years }\end{array}$ \\
\hline PVC & $\begin{array}{l}\text { Poly- } \\
\text { ester }\end{array}$ & $\begin{array}{l}\text { - Little heat insulation, but can be } \\
\text { made non } \\
\text { Inflammable and cold resistant. - can } \\
\text { be made in numerous colours } \\
\text { - More transparent fabric has shorter } \\
\text { service life. } \\
\text {-Some additional top coatings are } \\
\text { added to provide more resistance to } \\
\text { the PVC-coated fabric. }\end{array}$ & $\begin{array}{l}\text { Temporary } \\
\text { structures, } \\
\text { permanent } \\
\text { structures, } \\
\text { retractable } \\
\text { structures and } \\
\text { small scale to } \\
\text { large-scale } \\
\text { structures }\end{array}$ & $\begin{array}{l}\text {-High } \\
\text { frequency } \\
\text { welding } \\
\text {-Hot air } \\
\text { welding } \\
\text {-Hot wedge } \\
\text { welding } \\
\text { - stitching }\end{array}$ & $\begin{array}{l}\text { Very } \\
\text { econom } \\
\text { ical }\end{array}$ & $\begin{array}{l}10-15 \\
\text { years }\end{array}$ \\
\hline ETFE & Foil & $\begin{array}{l}\text { - Only suitable for small spans } \\
\text { because it is less tear resistant. } \\
\text { - It has a lower load bearing strength } \\
\text { than woven fabric. However, it has } \\
\text { greater spans than glass. } \\
\text {-It is fully recyclable with self- } \\
\text { cleaning surface. }\end{array}$ & & & & $\begin{array}{l}\text { more } \\
\text { than } 40 \\
\text { years }\end{array}$ \\
\hline Silicone & $\begin{array}{l}\text { Fibre- } \\
\text { glass } \\
\text { weave }\end{array}$ & $\begin{array}{l}\text { The fabric can be made very } \\
\text { translucent, which is claimed to be as } \\
\text { high as } 25 \% \text { translucency for the } \\
\text { architectural membrane. }\end{array}$ & $\begin{array}{l}\text { Temporary, } \\
\text { retractable, } \\
\text { permanent } \\
\text { structures, } \\
\text { midsize and } \\
\text { large-scale. }\end{array}$ & $\begin{array}{l}\text { Thermic } \\
\text { welding } \\
\text { with } \\
\text { adhesive } \\
\text { tape. }\end{array}$ & & \\
\hline PTFE & $\begin{array}{l}\text { Fibre- } \\
\text { glass } \\
\text { weave }\end{array}$ & $\begin{array}{l}\text { - It has advantages on durability long } \\
\text { term, appearance, superior fire rating, } \\
\text { resistance to ultraviolet light and light } \\
\text { reflectance. } \\
\text { - It has high transparence but can also } \\
\text { be printed. Unlike most fiberglass } \\
\text { fabrics, it can be welded and made } \\
\text { waterproof by special coating. }\end{array}$ & $\begin{array}{l}\text { Permanent, } \\
\text { midsize and } \\
\text { large-scale } \\
\text { structures. } \\
\text { Frequently } \\
\text { used when } \\
\text { long lifespan is } \\
\text { required }\end{array}$ & $\begin{array}{l}\text { Thermic } \\
\text { welding } \\
\text { with } \\
\text { adhesive }\end{array}$ & $\begin{array}{l}4-5 \\
\text { times } \\
\text { the } \\
\text { price of } \\
\text { pve off } \\
\text { the roll }\end{array}$ & $\begin{array}{l}\text { more } \\
\text { than } \\
25 \text { years }\end{array}$ \\
\hline $\begin{array}{l}\text { PTFE or } \\
\text { Silicone }\end{array}$ & $\begin{array}{l}\text { aramid } \\
\text { weave }\end{array}$ & $\begin{array}{l}\text { - It has high strength; it can be used } \\
\text { for special applications. With a strain } \\
\text { of } 5-6 \% \text { and a tensile strength of } \\
24,500 \mathrm{~N} / 5 \mathrm{~cm} \text {, it is by far the } \\
\text { strongest synthetic membrane }\end{array}$ & $\begin{array}{l}\text { Large-scale } \\
\text { structures } \\
\text { special } \\
\text { applications } \\
\text { Only used }\end{array}$ & Welding & & \\
\hline
\end{tabular}




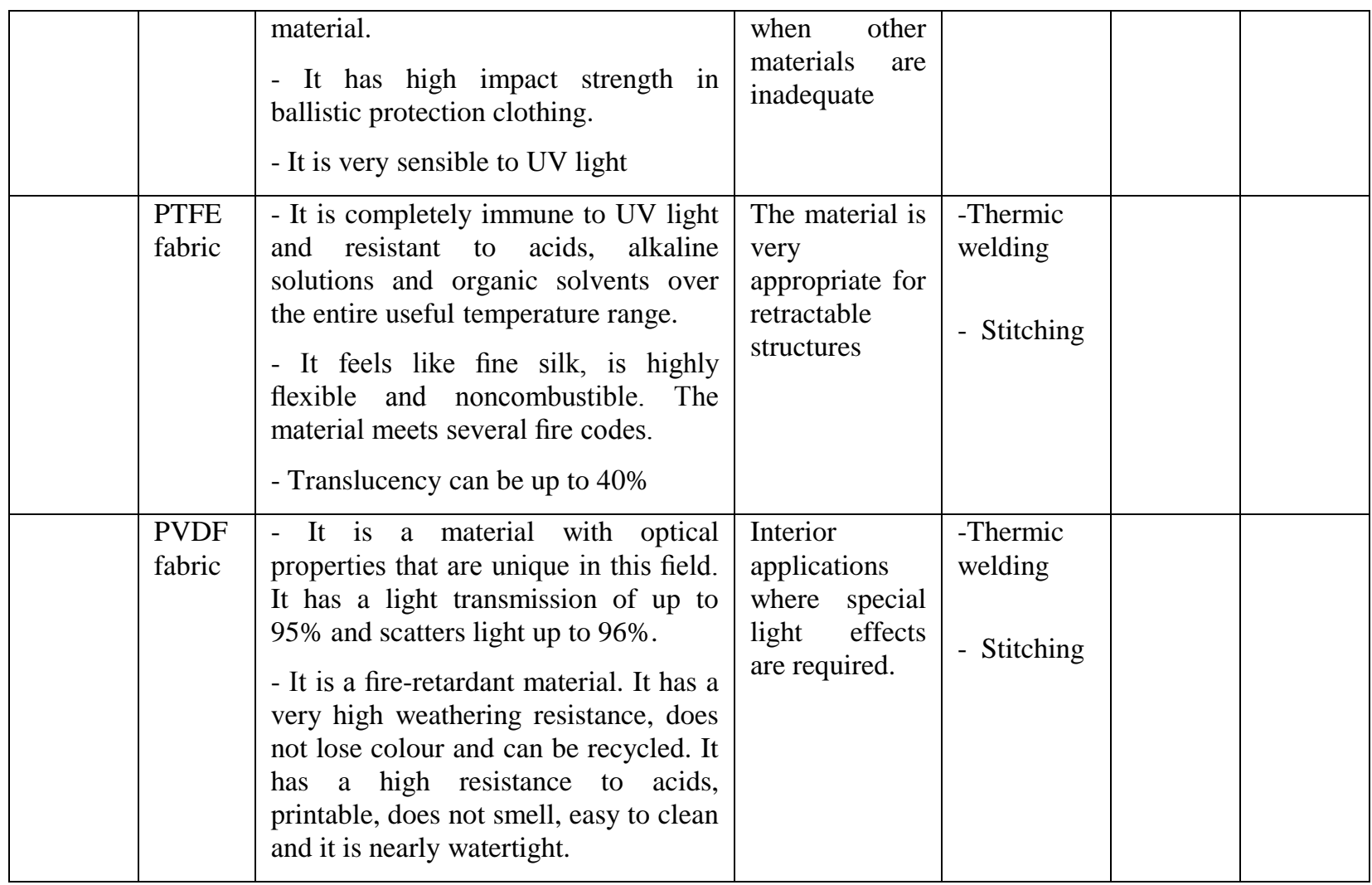

\section{Fabric Architecture valuation:}

\subsection{Fabric Architecture advantage:}

1- Unique designs

2- Clear-Span Design

3- Allow natural light for Lower Operating Costs

4- Ventilation

5- Easily Relocated (Portable)

6- Quick to Install

7- Lower Project Cost

8- Low-maintenance

9- Foundation Options

10- High strength weight ratio

11- Support sustainability

12- Longer life cycle of materials

13- Easy to transport

Costs point of view

Fabric structures offer many cost advantages:

- Low material costs

- Less materials required to cover a given space

- Lower replacement, require much shorter installation times, requiring less labor and materials

- Energy savings (Specialised Textiles Association of Australia 2013) 
fabric-vs-conventional-buildings

\begin{tabular}{|c|c|c|c|}
\hline Feature & Fabric & Polebarn & Metal \\
\hline Portable & $\checkmark$ & & \\
\hline Easy to decommission or relocate & $\checkmark$ & & \\
\hline Low maintenance & $\checkmark$ & & \\
\hline No painting or shingling required & $\checkmark$ & & \\
\hline Ability to insulate, add electrical \& lighting, etc. & $\checkmark$ & $\checkmark$ & $\checkmark$ \\
\hline Easy to access walls for changes or upgrades & $\checkmark$ & & \\
\hline Easy to reconfigure; change doors, add accesses, etc. & $\checkmark$ & & \\
\hline Easy to increase square footage & $\checkmark$ & & \\
\hline Translucent properties (natural light) & $\checkmark$ & & \\
\hline Meets site specific building codes & $\checkmark$ & $\checkmark$ & $\boldsymbol{V}$ \\
\hline Clear span design & $\checkmark$ & $\checkmark$ & $\checkmark$ \\
\hline Easy to repair & $\checkmark$ & & \\
\hline Warm in winter/cool in summer & $\checkmark$ & & \\
\hline Easy to construct in remote locations & $\checkmark$ & & \\
\hline Quiet, hushed atmosphere & $\checkmark$ & & \\
\hline Multiple color options & $\checkmark$ & $\checkmark$ & $\checkmark$ \\
\hline Naturally bright/free of shadows & $\checkmark$ & & \\
\hline Accommodates large overhead doors & $\checkmark$ & $\checkmark$ & $\checkmark$ \\
\hline Accommodates eaves & $\checkmark$ & $\checkmark$ & $\checkmark$ \\
\hline Types of Foundations & Fabric & Polebarn & Metal \\
\hline Concrete Blocks & $\checkmark$ & & \\
\hline Concrete Footing & $\checkmark$ & $\checkmark$ & $\checkmark$ \\
\hline Concrete Pilings & $\checkmark$ & & $\checkmark$ \\
\hline Concrete Slab & $\checkmark$ & $\checkmark$ & $\checkmark$ \\
\hline Concrete Wall & $\checkmark$ & & $\checkmark$ \\
\hline Ground Anchors & $\checkmark$ & & \\
\hline Posts & $\checkmark$ & $\checkmark$ & \\
\hline Screwpiles & $\checkmark$ & & $\checkmark$ \\
\hline Shipping Containers & $\checkmark$ & & \\
\hline
\end{tabular}

fig (4): Fabric vs conventional buildings. www.norsemanstructures.com

\subsection{Fabric Architecture disadvantage:}

1- Little to no rigidity

2- Affected badly by friction and UV rays

3- Large foundations are often required in order to prevent the wind lifting the canopy and taking it away. However, in terms of cost, foundations are a lot easier and cheaper to prepare than visible, above ground constructions that are exposed to weather and damage.

4- Where the fabric structure, is very small the tensile canopy may not offer the best solution in terms of cost. It would still require that all connections are engineered and checked, it would still require for patterning to be carried out, the steel fabricator would still need to fabricate awkward angles and special corner plates, so the overall cost per square meter could be much higher than if a fixed structure was used instead. Essentially, fabric structures offer great economies of scale - small structures can cost three or four times more per square meter than larger structures. While this is true to a degree with all construction types, we believe the effect is much more extreme with tensile structures. (Span-design 2010)

5- Need sound Design and Engineering as Building can't stand up for long time if the connections and the used panels materials are not good ,in addition some designs are not good because the hardness of making connections well also additional loads from snow or wind, affect the structure www.legacybuildingsolutions.com . 


\section{Fabric Architecture in Egypt:}

1. The history of the Fabric structures in Egypt is back to the Pharaonic era (simple appearance) then it flourished more in the Islamic era especially in (Mamaleek period) but its usage remained limited to forms of industrial and artistic works far away from architecture (الخياط 2002).

2. Fabrics was not one of the elements of ancient Egyptian civilization, it mainly depends on other local materials that considered more durable than fabrics.

3. So far, fabric architecture is not widespread in Egypt, it has a simple appearance as a shading system and some simple projects, other medium scale projects are using only PVC fabrics and HDPE (High Density Polyethylene) and there are one example for reinforced fabrics like PTFE or ETFE which are accounted of the most fabrics used in modern architectural projects.

Table (3): Comparison between common fabrics used in Egypt

\begin{tabular}{|c|c|c|c|c|c|c|}
\hline & \multicolumn{2}{|c|}{ Polyester } & \multicolumn{2}{|c|}{$\begin{array}{c}\text { HDPE } \\
\text { (High Density Polyethylene) }\end{array}$} & \multicolumn{2}{|c|}{ PTFE } \\
\hline Properties & \multicolumn{2}{|c|}{$\begin{array}{c}\text { have to add top coatings a to provide } \\
\text { more resisitenace to the PVC-coated } \\
\text { fabric } \\
\text { offers excellent weight to strength } \\
\text { ratios } \\
\text { can be made non inflammable and } \\
\text { cold resistant } \\
\text { can be made in numerous colours }\end{array}$} & \multicolumn{2}{|c|}{$\begin{array}{c}\text { has high Ultra Violet (UV) protection } \\
\text { has less shrinkage and offers excel- } \\
\text { lent weight to strength ratios and light- } \\
\text { er than PVC in general } \\
\text { can be made non inflammable and } \\
\text { cold resistant } \\
\text { can be made in numerous colours }\end{array}$} & \multicolumn{2}{|c|}{$\begin{array}{c}\text { It is completely immune to UV light and resistant - } \\
\text { to acids, alkaline solutions and organic solvents } \\
\text { over the entire useful temperature range } \\
\text { It feels like fine silk, is highly flexible and } \\
\text { noncombustible } \\
\text { The material meets several fire codes } \\
\text { Translucency can be up to } 40 \%\end{array}$} \\
\hline Efficiency + life span & \multicolumn{2}{|c|}{$15-20$ years } & \multicolumn{2}{|c|}{ 15-years } & \multicolumn{2}{|c|}{ more than 25 years } \\
\hline $\begin{array}{l}\text { Manufacturing } \\
\text { Techniques }\end{array}$ & \multicolumn{2}{|c|}{$\begin{array}{l}\text { stitching / High-frequency welding } \\
\text { Hot-air welding / Hot-wedge welding }\end{array}$} & \multicolumn{2}{|c|}{$\begin{array}{l}\text { stitching / High-frequency welding } \\
\text { Hot-air welding / Hot-wedge welding }\end{array}$} & \multicolumn{2}{|c|}{ Thermic welding with adhesive } \\
\hline Cost (2015) & $\simeq 5-10$ Euro $/ \mathrm{m}$ & for min. thickness & $\simeq 4-7$ Dollar/m & for min. thickness & $\simeq 40$ Euro $/ \mathrm{r}$ & \\
\hline Usage & \multicolumn{4}{|c|}{ Facade - Modular structures - Interior architecture and Design - Solar protection } & \multicolumn{2}{|c|}{$\begin{array}{l}\text { Permanent, midsize and large-scale structures } \\
\text { Frequently used when long lifespan is required }\end{array}$} \\
\hline \multirow{2}{*}{$\begin{array}{l}\text { Important } \\
\text { projects }\end{array}$} & $\begin{array}{l}\text { Global } \\
\text { Stadiums - Airports - } \\
\text { - Halls - Universties }\end{array}$ & $\begin{array}{c}\text { in Egypt } \\
\text { Airports - Halls - }\end{array}$ & \begin{tabular}{|c|} 
Global \\
Tensile Membranes - \\
Framed Shade Structure
\end{tabular} & $\begin{array}{c}\text { in Egypt } \\
\text { Tensile Membranes - } \\
\text { Framed Shade Structure }\end{array}$ & Global & in Egypt \\
\hline & $\begin{array}{l}\text { Eastern Michigan Universi- } \\
\text { ty indoor practice field } \\
\text { USA }\end{array}$ & $\begin{array}{l}\text { Sports halls, Military school. } \\
\text { Cairo, Egypt }\end{array}$ & $\begin{array}{l}\text { Shed in Phoenix, Arizona, } \\
\text { USA }\end{array}$ & $\begin{array}{l}\text { Shed in British school, Cairo - } \\
\text { Egypt }\end{array}$ & Millennium Dome, London, UK & 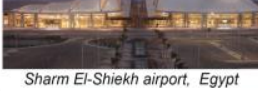 \\
\hline
\end{tabular}

\section{Design of fabric structure}

With the ability to span large distances in a structurally efficient way, tension membrane structures offers a lot of interesting possibilities; from a sustainable, engineering and an architectural perspective. (Henrysson 2012). Fabric materials used for tent structures are form-active, behave non-linearly and anisotropically, and can only transfer loads through tension. Due to this, designing and modelling such structures is quite complicated and different from traditional structures (Linthout. 2016).

It is well known that the shape of a structure determines its mechanical behaviour and that this principle of 'form follows force' can be used to structurally inform architectural design (Veenendaal and Block 2012).

\subsection{Design process}

1- Select boundary conditions

- support locations

- Edge details

- Pre-stress to be applied

2- Form-finding of surface shape using e.g.

- Dynamic relaxation

- Force-density 
Form finding is a term used for many different methods to find the shape of structures of varying kind. Usually it is the structurally optimal shape that is the goal (Henrysson 2012).

The shape of form-active structures is not known in advance and requires a process called form finding or shape finding (Veenendaal and Block 2012).

3- Determine stresses in membrane under service conditions (e.g. snow, wind loads) using structural finite element analysis software

4- Select appropriate material

5- Fabrication and installation

- Cutting of fabric

- Radio-frequency or heated bar welding (usually)

- Assembly into fields

- Tensioning between boundaries

\subsection{General forms}

Fabric structures are sensitive to changes in geometry, material properties, and warp span direction.

Generally, tensioned fabric structures are designed to three basic shapes - conic, saddle, and arches, or their combinations as figure 10 , and the surface geometries with the doubly curved shapes, are complicated by the supporting boundary. To achieve the stress balance within the surface, the two main curvatures at any point of the surface are opposite. For a uniformly stressed membrane surface, zero mean curvatures (two same large main curvatures but opposite) are found at any point of the surface (Zhang 2010).

- Saddle roof

- Mast supported

- Arch supported

- Point supported

- Combinations (http://www.slideshare.net/)

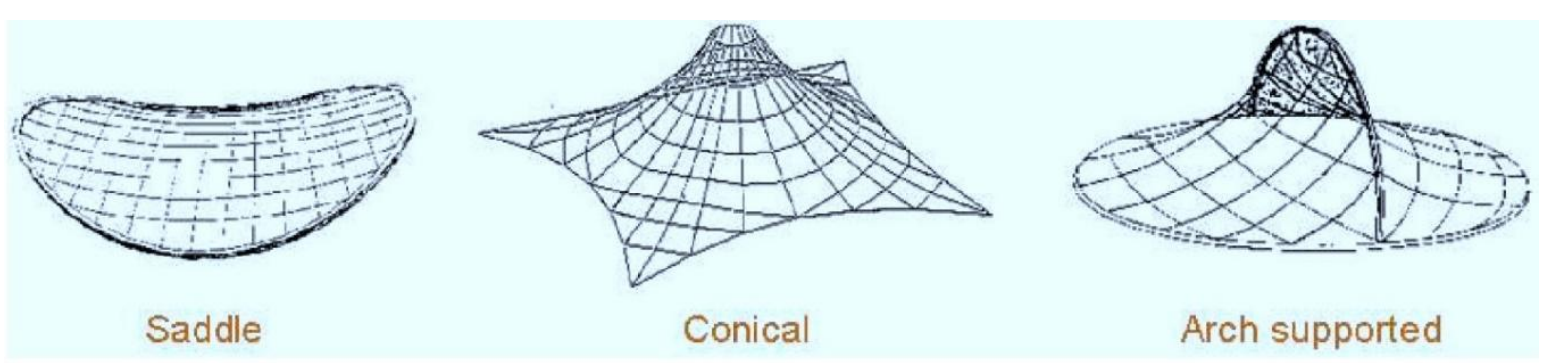

Fig (5): Three basic shapes of modern fabric structures

\section{Fabric Facades}

\subsection{What Are Tensile Façades?}

Tensile Facades (also called textile, fabric or flexible facades) are an innovative, long lasting, cost effective alternative to traditional metal mesh façade screens (as low as a 1/3 of the cost). This exterior "2nd skin" building system acts as a screening or shading device. Tensile Façades can come in various forms and shapes and can span great distances with less structural support than traditional materials. It typically consists of an clean modern aluminum framing system, custom steel brackets (if required) and a cladding material that is either a tensile mesh, tensile membrane or tensile clear foil (Coated-PES, PTFE Fiberglass, or ETFE Foil). Many manufacturer cladding materials are $100 \%$ recyclable and have a minimum of a 10 -year warranty and 18 to 30 year life expectancy.

\subsection{APPLICATIONS}

- Building Sun Screens

- Stadium Screening/Branding

- Parking Garage Screens

- Surface Mounted

- Cantilevered (Custom Structural Steel Brackets)

The following table includes the application of fabric facades in Egypt.

The survey in this research was made in two of the most areas which include modern buildings in Egypt (AlTeseen Street in new Cairo and the Smart village), as the Smart village has the Headquarters for many international companies and Al-Teseen Street in new Cairo has many headquarters for a number of major companies and banks and it is an entertainment, administrative, commercial and medical forum. 
Table (5): Fabrics tensile façade applications.

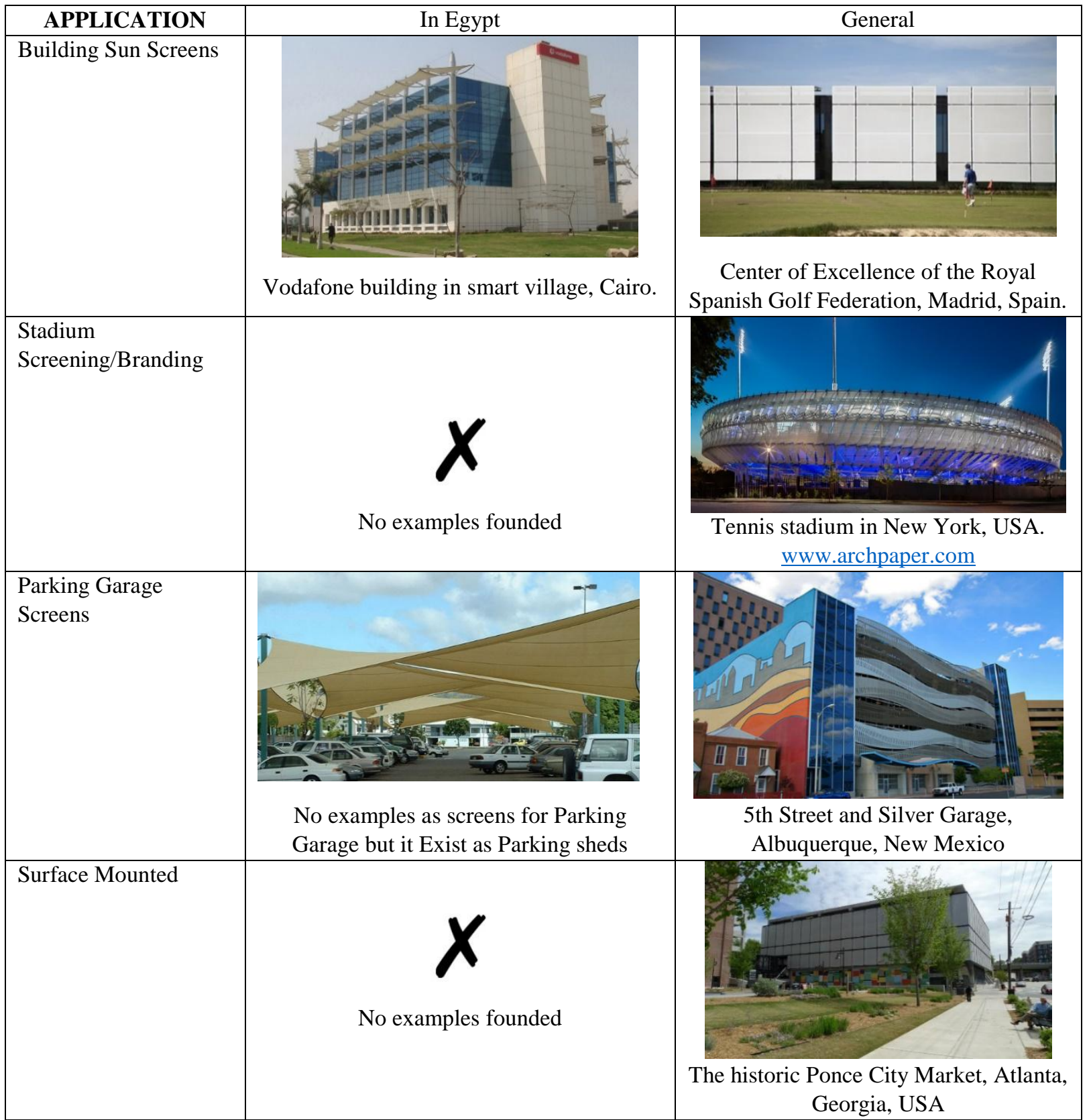

\subsection{ARCHITECTURAL FUNCTIONS \& BENEFITS} BENEFITS :

- Economical Alternative to Metal Mesh or Perforated Metal

- Innovative Shading/Screening

- Dramatic Energy Savings

- Green/ up to100\% Recyclable

- Maintain Visual Transparency

- Opaque During the Day, Translucent at Night

- Breathable/Lightweight

- Changeable Building Graphics/Branding*

- $\quad$ Proven 25+ Year Life Expectancy*

- Modern Look/Clean Clamping Details

\section{FUNCTIONS :}

Fabric façade functions which are found in Egypt for tensile façades, are applied as a tensile elements connected to façades. 
Table (6): Tensile Façades functions.

\begin{tabular}{|c|c|c|}
\hline FUNCTIONS & In Egypt & General \\
\hline $\begin{array}{l}\text { Thermal comfort \& } \\
\text { solar protection }\end{array}$ & $\begin{array}{l}\text { Vodafone building in smart village, } \\
\text { Cairo, Egypt. Source: the researcher }\end{array}$ & Office building - Spain \\
\hline $\begin{array}{l}\text { Visual comfort \& } \\
\text { Glare control }\end{array}$ & $\begin{array}{l}\text { Internal curtains not external on } \\
\text { façade. }\end{array}$ & 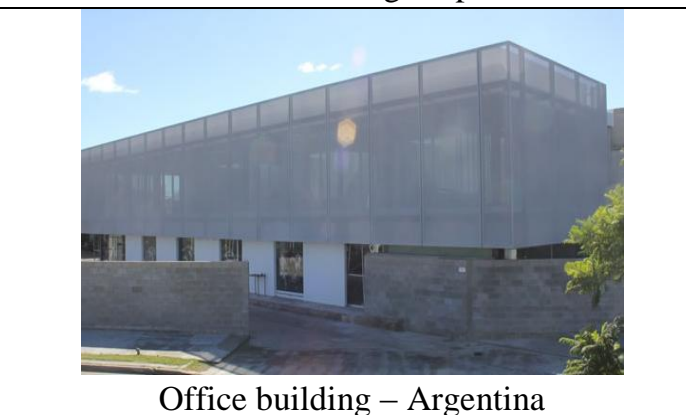 \\
\hline $\begin{array}{l}\text { Natural light \& } \\
\text { visibility towards } \\
\text { outside }\end{array}$ & No examples founded & Panamerican University, Guadalajara - Mexico. \\
\hline Wind protection & $\begin{array}{l}\text { Vodafone building in smart village, } \\
\text { Cairo, Egypt. Source: the researcher }\end{array}$ & Rungis railway station - France. \\
\hline
\end{tabular}




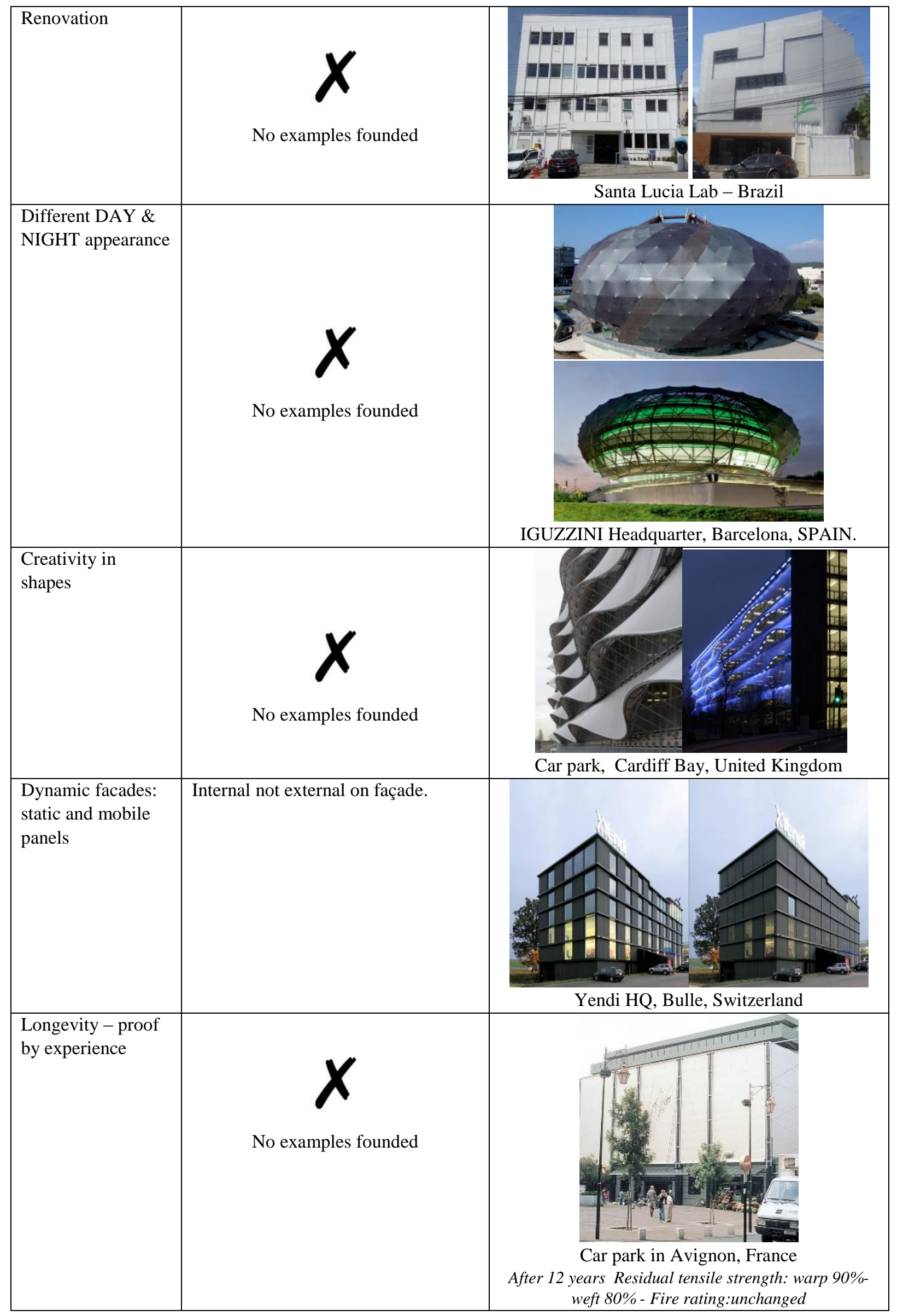




\section{CONCLUSION}

\section{Fabric structure in Egypt today}

The fabric structure has been devolved in Egypt in the last years because of its various benefits and cost efficiency, but it still has limited applications because of the traditional buildings culture still more common in use. After review many projects which use fabric in some parts of its design, we find that the modern techniques of fabric structures are not used in Egypt, it used in Egypt widely as a shading system not a construction building material.

As a shading system the implementation companies in Egypt import the fabric materials from foreign countries then they make the design and other fabrication process such as pattering, cutting and welding or stitching then it assembled into field.

After review some factories and fabric companies, we list the common used fabric materials in Egypt as shown in table (3) which list the fabric materials that commonly used in Egypt, its usage and its manufacturing properties, we find that developed fabric materials still in limited use in Egypt at present, and the common use of it is in the interior designs, shading system and small scale projects.

By comparing fabric architecture projects in Egypt to that in other countries, we find that project levels in Egypt still in the beginnings and have simple appearance according to financial and cultural reasons.

PVC fabric comes first as it is the most used fabric in Egypt because it is used in small scale projects and it has low price relatively, then PTFE comes after; presented in Sharm El-Sheikh airport.

We expect that fabric architecture will expand as a type of lightweight buildings in the upcoming years due to its advantages.

\section{References}

1. Chilton, P. J. (2009). Webs, nets and tensile structures in architecture, Nottingham Trent University.

2. Henrysson, E. (2012). "Conceptual design and analysis of membrane structures."

3. Josep Ignasi de Llorens (2015). Fabric structure in architecture UK, USA Woodhead

4. Linthout., T. (2016). Form-finding and patterning of fabric structures using shape optimization techniques.

5. Span-design. (2010). "Pros and Cons of Fabric Structures." from http://www.spandesign.com/technical/article pros and cons of fabric structures. aspx.

6. Specialised Textiles Association of Australia (2013). About Fabric Structures, FABRIC STRUCTURES COMMITTEE REPORT.

7. Veenendaal, D. and P. Block (2012). "35 Computational form-finding of fabric formworks: an overview and discussion."

8. Zhang, L. (2010). "Reliability analysis of fabric structures."

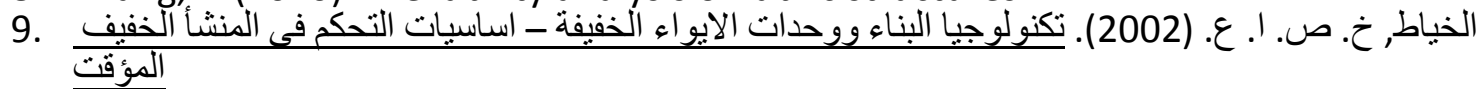

\section{World Wide Web}

1. https://www.empowerconstruction.com.au

2. http://www.norsemanstructures.com

3. https://www.designingbuildings.co.uk

4. http://alaskastructures.com

5. http://www.slideshare.net

6. www.birdair.com

7. http://www.legacybuildingsolutions.com

8. https://segd.org

9. http://www.buildnova.com

10. Www.ifai.com

11. https://www.dezeen.com

12. wwW.airsculpt.com 